\title{
ANALISIS RUGI DAYA DAN REKONSILIASI ENERGI JARINGAN DISTRIBUSI TEGANGAN MENENGAH 20 KV PADA PENYULANG NIJANG
}

\author{
Ahmad Jaya1, Wirentake $^{2}$, Mei Priyanto ${ }^{3}$ \\ Program Studi Teknik Elektro Universitas Teknologi Sumbawa \\ Fakultas Teknik Universitas Teknologi Sumbawa \\ *Corresponding Author email: ahmad.jaya@uts.ac.id, wirentake@uts.ac.id
}

\begin{tabular}{|c|c|}
\hline & ABSTRAK \\
\hline Diterima : & $\begin{array}{l}\text { Penelitian ini bertujuan untuk mengetahui susut/rugi daya pada penyulang nijang melalui } \\
\text { proses rekonsiliasi energi, simulasi program ETAP } 12.6 \text {, dan perhitungan manual. }\end{array}$ \\
\hline $\begin{array}{l}\text { Bulan September } \\
2020\end{array}$ & $\begin{array}{l}\text { Manfaat penelitian ini dapat dijadikan dasar pertimbangan terhadap upaya perbaikan yang } \\
\text { sebaiknya dilakukan untuk memperkecil susut/rugi daya pada jaringan distribusi tegangan } \\
\text { menengah penyulang nijang. Metode yang digunakan adalah metode penelitian }\end{array}$ \\
\hline Diterbitkan & kuantitatif karena mengambil data dari pengukuran titik transaksi yang kemudian \\
\hline $\begin{array}{l}\text { Bulan } \quad \text { Oktober } \\
2020\end{array}$ & $\begin{array}{l}\text { dibandingkan dengan hasil pada program simulasi ETAP } 12.6 \text { dan perhitungan manual. } \\
\text { Hasil penelitian menunjukan besar (kWh) susut daya yang dihasilkan dari } 3 \text { proses } \\
\text { didapatkan bahwa proses rekonsiliasi energi menghasilkan susut/rugi daya lebih besar }\end{array}$ \\
\hline Keyword: & yaitu $10.657 \mathrm{kWh}$, pada simulasi ETAP 12.6 menghasilkan susut/rugi daya sebesar 3049 \\
\hline Susut/Rugi Daya, & $\mathrm{kWh}$ dan pada perhitungan manual menghasilkan susut/rugi daya sebesar $4199 \mathrm{kWh}$, dari \\
\hline $\begin{array}{l}\text { Penyulang } \\
\text { Niiang }\end{array}$ & hasil penelitian dapat diketahui bahwa pada proses simulasi ETAP 12.6 dan perhitungan \\
\hline Nijang, & manual hanya menghitung susut/rugi daya karena penyebab teknis sedangkan proses \\
\hline Rekonsiliasi & rekonsiliasi energi sudah termasuk penyebab teknis dan nonteknis. Diharapkan dengan \\
\hline Energi, Etap & $\begin{array}{l}\text { penelitian ini dapat mendukung upaya perbaikan susut/rugi daya di lingkungan PT PLN } \\
\text { (Persero) UP3 Sumbawa. }\end{array}$ \\
\hline
\end{tabular}

\section{PENDAHULUAN}

Peningkatan ketersediaan kuantitas energi listrik terus dilakukan oleh PT PLN (Persero) dan seiring bertambahnya beban, maka perubahan terhadap sistem tenaga listrik tidak dapat terhindarkan. Selaras dengan itu, peningkatan kualitas penyaluran tenaga listrik juga menjadi hal yang sangat penting yang terus menjadi perhatian. Binilang (2017) menyatakan bahwa yang menjadi penentu kualitas penyaluran adalah kehandalan dan efisiensi.

Penyaluran tenaga listrik di wilayah Sumbawa meliputi Jaringan Tegangan Tinggi (JTT) 70 KV, Jaringan Tegangan Menengah (JTM) 20 KV, dan Jaringan Tegangan Rendah (JTR) $220 \mathrm{~V} /$ $380 \mathrm{~V}$. Untuk pendistribusian energi listrik yang handal dan efisien, maka semua hal yang dapat menimbulkan kerugian harus dikaji dengan baik. Menurut Marniati (2018), susut daya atau rugi daya listrik adalah berkurangnya daya listrik dalam proses penditribusian dari unit pembangkit menuju beban (konsumen), yang disebabkan oleh adanya tahanan jenis penghantar yang dipengaruhi oleh arus dan tegangan saat penyaluran energi listrik dilakukan. Secara umum penyusutan daya dapat dibagi menjadi dua jenis yaitu : (1) Susut teknis, Penyusutan teknis adalah penyusutan yang terjadi sebagai akibat adanya resistansi pada peralatan pembangkitan maupun peralatan penyaluran dalam transmisi dan distribusi sehingga terdapat daya yang hilang, dan (2) Susut non teknis, penyusutan secara non teknis adalah susut yang disebabkan oleh kesalahan dalam pembacaan alat ukur, kesalahan kalibrasi di alat ukur, dan kesalahan akibat bersifat administratif lainnya.

PT PLN (Persero) UP3 Sumbawa sudah melaksanakan proses perhitungan secara akumulatif terhadap perhitungan rugi-rugi daya (susut teknis) namun belum dilaksanakan secara terperinci penyaluran distribusinya. Oleh karena itu, dipandang perlu untuk melakukan sebuah studi perhitungan dan analisis penyaluran distribusi. Disisi lain, program rekonsiliasi energi juga dapat dilaksanakan untuk menghitung susut daya secara langsung dengan memasang titik transaksi di peralatan.

Adapun tujuan dari penelitian ini secara terperinci yakni untuk mengetahui rugi-rugi daya pada saluran sistem $20 \mathrm{KV}$ menggunakan aplikasi ETAP 12.6 dan mengetahui nilai susut daya serta proses rekonsiliasi energy pada Penyulang Nijang. Sementara itu, alasan dipilihnya Penyulang Nijang sebagai tempat dilakukannya peneltian yakni karena di Penyulang Nijang sudah dilakukan pemasangan titik transaksi pada gardu sehingga dapat dilaksanakan rekonsiliasi energi.

\section{LANDASAN TEORI}

\section{Sistem Tenaga Listrik}

PLN (2010) tentang kriteria disain enjinering kontruksi jaringan distribusi tenaga listrik menjelaskan bahwa suatu sistem tenaga listrik 
secara sederhana terdiri atas sistem pembangkit, sistem transmisi dan gardu induk, sistem distribusi dan sistem sambungan pelayanan. Sistem-sistem tersebut saling berkaitan dan membentuk suatu sistem tenaga listrik.

Sistem Distribusi Tegangan Menengah mempunyai tegangan kerja di atas $1 \mathrm{kV}$ dan setinggi-tingginya $35 \mathrm{kV}$. Sistem Distribusi Tegangan Rendah mempunyai tegangan kerja setinggi-tingginya $1 \mathrm{kV}$. Jaringan distribusi Tegangan Menengah berawal dari Gardu Induk/Pusat Listrik pada sistem terpisah/isolated. Pada beberapa tempat berawal dari pembangkit listrik. Bentuk jaringan dapat berbentuk radial atau tertutup (radial open loop). Jaringan distribusi Tegangan Rendah berbentuk radial murni. Sambungan Tenaga Listrik adalah bagian paling hilir dari sistem distribusi tenaga listrik. Pada Sambungan Tenaga Listrik tersambung Alat Pembatas dan Pengukur (APP) yang selanjutnya menyalurkan tenaga listrik kepada pemanfaat.

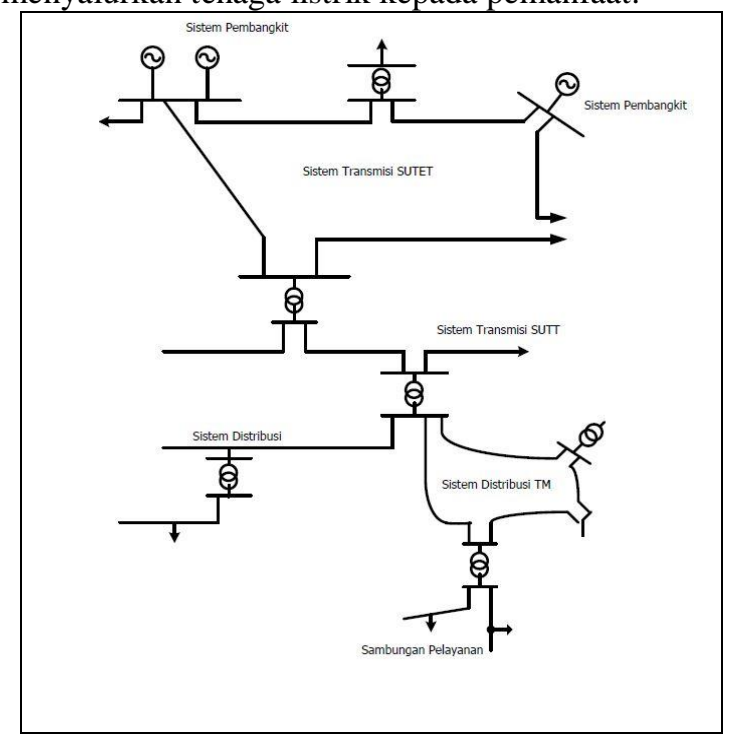

Gambar pola sistem tenaga listrik

\section{Gardu Distribusi}

Seperti PLN (2010) tentang kriteria disain enjinering kontruksi jaringan distribusi tenaga listrik menjelaskan bahwa gardu distribusi adalah bangunan gardu transformator yang memasok kebutuhan tenaga listrik bagi para pemanfaat baik dengan tegangan menengah maupun tegangan rendah. Gardu distribusi merupakan kumpulan / gabungan dari perlengkapan hubung bagi baik tegangan menengah dan tegangan rendah. Jenis perlengkapan hubung bagi tegangan menengah pada gardu gistribusi berbeda sesuai dengan jenis konstruksi gardunya. Konstruksi gardu dibedakan menjadi 2 jenis yakni gardu distribusi konstruksi pasangan luar dan gardu distribusi pasangan dalam.

\section{Electric Transient and Analysis Program (ETAP)} 12.6
Pramono, dkk (2018) ETAP merupakan program analisa grafik transient kelistrikan yang dapat dijalankan dengan menggunakan program Microsoft ${ }^{\circledR}$ Windows ${ }^{\circledR}$ 2000, XP, Vista, 7, dan 8. ETAP merupakan alat analisa yang komprehensif untuk desain dan testing power sistem. Program ETAP dibuat oleh perusahaan Operation Technology, Inc (OTI) dari tahun 1983. Tujuan program ETAP 12.6.0 dibuat adalah untuk memperoleh perhitungan dan analisis sistem tenaga menggunakan komputer. ETAP memungkinkan penggunanya dengan mudah untuk membuat dan mengedit Single Line Diagram (SLD), sistem kabel bawah tanah, sistem kabeltiga dimensi, dan grounding grid tiga dimensi. Program ini didesain dengan tiga konsep utama, yaitu :

\section{METODE PENELITIAN}

Penelitian ini menerapkan pendekatan kuantitatif. Menurut Sugiyono (2011) penelitian kuantitatif adalah penelitian berupa angka-angka dan analisis analisis menggunakan statistik. Sementara Menurut Amiruddin (2010) Penelitian kuantitaif adalah penelitian yang dilakukan dengan pengumpulan data dan menggunakan daftar pertanyaaan berstruktur (angket) yang disusun berdasarkan pengukuran terhadap variabel yang diteliti yang kemudian menghasilkan data kuantitatif. Sedangkan menurut Ahmad Suyitno dan Tanzeh (2006), yang dimaksud penelitian kuantitatif adalah penelitian yang menitik beratkan pada penyajian data yang berbentuk angka atau kualitatif yang diangkakan (skoring) yang menggunakan statistik. Dengan kata lain, dalam penelitian kuantitatif peneliti berangkat dari sebuah teori (menguji sebuah teori) menuju data dalam bentuk angka dan berakhir pada penerimaan atau penolakan dari teori yang telah diuji kebenarannya. Penelitian kuantitatif bertumpu sangat kuat pada pengumpulan data. Data yang dimaksud berupa data yang diperoleh dari hasil pembacaan titik transaksi untuk dimasukan dilakukan perhitungan dan analisa. Karena itu, dalam penelitian ini statistik memegang peran sangat penting sebagai alat untuk menganalisis jawaban suatu masalah.

\section{Tahapan Penelitian}

Tahapan penelitian ini terdiri dari beberapa tahapan, yaitu : 1) Simulasi Aliran Daya Mengguanakan ETAP 12.6 untuk meengetahui susut daya, 2) Perhitungan Susut Daya menggunakan teori listrik terapan, dan 3) Rekonsiliasi Energi berdasarkan titik transaksi energi, ketiganya akan di analisa sebagai bahan pembanding dengan harapan akan mendapatkan nilai susut daya yang akan dijadikan acuan untuk melakukan hasil tindak lanjutnya untuk PLN. Berikut detail tahapan yang dilakukan peneliti:

1. Simulasi Aliran Daya Menggunakan ETAP 12.6 Pada bagian ini tahapan di mulai dengan 
pembuatan SLD sesuai dengan data eksisting sistem kelistrikan Sumbawa Besar, proses pengolahan data dan input hasil olah data kedalam SLD pada ETAP 12.6, kemudian dilakukan tahapan lanjutan untuk analisis hasil simulasi. Berikut tahapan yang dilakukan peneliti pada bagian ini :

a. Tahap pengolahan data

Tahap pengolahan data ini merupakan tahap untuk mengklasifikasi bagian-bagian dari data yang didapatkan sesuai dengan kegunaannya masing-masing. Data yang dibutuhkan untuk penelitian ini berasal dari PT. PLN UP3 Sumbawa.

b. Tahap Input Data pada Simulasi ETAP 12.6 Tahap input dilakukan pada Single Line Diagram yang direpresentasikan kedalam ETAP 12.6 sesuai dengan data eksisting sistem kelistrikan Sumbawa Besar. Berikut adalah proses input data SLD pada simulasi program ETAP 16:

\section{1) Power Grid}

Power Grid / Kubikel yang dimasukan nama grid, Mode Operasi (Swing, $V$ control, dan Mvar control), rated $\mathrm{KV}$, MW, MVAR, dan lain lain.

2) Transformator

Data transformator yang dimasukkan adalah nama transformator, rated $\mathrm{KV}$ (primer dan sekunder), impedansi (\% Z dan $\mathrm{X} / \mathrm{R}$ ), dan fixed tap (\% tap).

3). Penghantar Distribusi

Data sistem transmisi dan penghantar distribusi yang di input adalah jenis penghantar pada transmisi seperti jenis konduktor, luas penampang, panjang jaringan, dll. Untuk jaringan distribusi dibutuhkan spesifikasi penghantar sesuai Standar PLN (SPLN).

4). Data Bus

Data bus yang dimasukkan adalah nama bus, nominal $\mathrm{KV}$, nilai tegangan $(\% \mathrm{~V})$ dan angle, dengan keadaan initial Voltage

5). Data Beban

Data beban sistem kelistrikan Sumbawa Besar yang digunakan adalah data beban yang terdapat pada data SLD dari PT. PLN (Persero) UP3 Sumbawa. Data ini diperoleh dari hasil rekonsialiasi energi supaya real. Jenis beban yang digunakan dalam SLD simulasi ETAP 12.6 ini adalah jenis static load. Data yang dimasukkan adalah beban aktif-reaktif, \% PF, dan lain lain.

\section{c. Tahap Pemodelan}

Tahap ini dilakukan dengan menjalankan simulasi dari data yang telah ter-input kedalam SLD pada ETAP 12.6. Pemodelan dilakukan dalam dengan kondisi beban sesuai dengan hasil pengambilan data transaksi di Pangkal Penyulang Nijang dan di ujung yaitu pada Trafo.

2. Rekonsiliasi Energi

Tahapan rekonsiliasi energi adalah tahapan dimana titik transaksi di hulu jaringan tengangan menengah dan hilir jaringan akan dibandingkan melalui titik transaksi yang sebelumnya telah terpasang. Tahapan yang dilakukan pada tahap ini antara lain; (1) Pembacaan Meter Transaksi,

(2) Pengolahan data Rekonsiliasi Energi.

a. Pembacaan Meter Transaksi

Pembacaan pertama dilakukan dengan membaca data Load Profil yang ada di KWh Transaksi yang berada di pangkal penyulang Nijang yaitu di PLTD Labuhan dan ujung penyulang yaitu di gardu - gardu yang berada di sepanjang jaringan Penyulang Nijang. Proses pembacaan menggunakan software bawaan KWh meternya.

b. Pengolahan data Rekonsiliasi Energi

Pengolahan data rekonsiliasi dilakukan dengan cara mengambil total KWh yang terpakai / KWh Produksi di pangkal dan rekapan seluruh KWh Pemakaian yang ada di Gardu selama periode yang sama. Data yang diperoleh dari hasil download berupa file .txt lalu data diolah menggunakan Microsoft office excel untuk di akumulasikan. Selain data KWh yang dihasilkan, profil tegangan dan nilai beban puncak pada beban juga dijadikan acuan dalam pengisian data di Simulasi Etap 12.6.

\section{HASIL DAN PEMBAHASAN}

\section{Rugi Daya Penyulang Nijang Pada Simulasi ETAP 12.6}

Analisis rugi daya pada Penyulang nijang dilakukan dengan perancangan SLD pada aplikasi ETAP 12.6, kemudian dimasukan parameter berdasarkan data yang asset penyulang nijang berupa penghantar dilengkapi dengan ukuran dan panjangnya pada tabel 4.1, dan gardu distribusi dilengkapi dengan kondisi beban pada tabel 4.2. Berikut ini tahapan proses analisa rugi daya pada Simulasi ETAP 12.6 :

1. Tahap Perancangan SLD

Tahap perancangan SLD yang dilakukan yaitu menambahkan bagian-bagian yang dibutuhkan diantaranya : power grid, penampang, trafo, pengaman, dan beban (load). Selanjutnya bagian-bagian tersebut digabungkan menggunakan bus.

2. Tahap Input Data pada ETAP 12.6 Pada tahap input data dilakukan pada bagian diantaranya : penampang, trafo, beban (load), dan power grid. Hal ini dilakukan karena akan berpengaruh pada hasil rugi daya. Data yang 
digunakan berasal dari data asset penyulang nijang untuk penghantar, data kapasitas trafo berdasarkan data asset trafo dan data beban (load) berdasarkan data rekonsiliasi energi.

3. Tahap Pemodelan

Tahap pemodelan ini dilaksanakan dengan menjalankan hasil perancangan dan input pada bagian bagian peralatan yang selanjutnya dilakukan simulasi untuk mengetahui rugi daya. Dari hasil simulasi didapatkan data hasil sebagai berikut :

Tabel Hasil Simulasi Susut Daya pada Aplikasi ETAP 12.6

\begin{tabular}{|c|c|c|}
\hline ID & $\begin{array}{c}\text { \% Voltage } \\
\text { Drop }\end{array}$ & kW Losses \\
\hline BL2 & 0,08 & 0,839 \\
\hline BL3 & 0,01 & 0,09 \\
\hline BL8 & 0 & 0,003 \\
\hline BL13 & 0 & 0,009 \\
\hline BL14 & 0,02 & 0,063 \\
\hline BL15 & 0,01 & 0,023 \\
\hline BL64 & 0,03 & 0,237 \\
\hline BL81 & 0 & 0,005 \\
\hline BL83 & 0,03 & 0,071 \\
\hline BL85 & 0,05 & 0,118 \\
\hline BL87 & 0 & 0,01 \\
\hline BL89 & 0 & 0,001 \\
\hline BL91 & 0 & 0 \\
\hline BL93 & 0 & 0,001 \\
\hline BL95 & 0,1 & 0,181 \\
\hline BL97 & 0 & 0,001 \\
\hline BL99 & 0 & 0 \\
\hline BL104 & 0,06 & 0,098 \\
\hline BL106 & 0 & 0,001 \\
\hline BL110 & 0,01 & 0,005 \\
\hline BL114 & 0,01 & 0,005 \\
\hline BL116 & 0,02 & 0,079 \\
\hline BL117 & 0,01 & 0,053 \\
\hline BL120 & 0 & 0,001 \\
\hline BL122 & 0 & 0 \\
\hline BL125 & 0 & 0,001 \\
\hline BL127 & 0 & 0 \\
\hline BL129 & 0 & 0 \\
\hline BL134 & 0 & 0,008 \\
\hline BL138 & 0 & 0 \\
\hline BL142 & 0 & 0,001 \\
\hline BL144 & 0 & 0,001 \\
\hline BL146 & 0 & 0 \\
\hline BL148 & 0 & 0,001 \\
\hline BL150 & 0 & 0 \\
\hline BL152 & 0 & 0,006 \\
\hline BL154 & 0 & 0 \\
\hline
\end{tabular}

\begin{tabular}{|c|c|c|}
\hline BL155 & 0,01 & 0,007 \\
\hline BL157 & 0,02 & 0,011 \\
\hline Line1 & 0,02 & 0,242 \\
\hline MH041 & 0,51 & 0,035 \\
\hline MH042 & 0,48 & 0,032 \\
\hline MH043 & 1,16 & 0,364 \\
\hline MH056 & 0 & 0 \\
\hline MH057 & 1,13 & 0,865 \\
\hline MH059 & 0,95 & 0,494 \\
\hline SKTM NIJANG & 0,02 & 0,262 \\
\hline SM028 & 1,77 & 1,365 \\
\hline SM043 & 1,58 & 1,083 \\
\hline SM073 & 1,66 & 1,5 \\
\hline SM079 & 2,06 & 1,826 \\
\hline SM093 & 1,27 & 0,22 \\
\hline SM098 & 1,38 & 0,831 \\
\hline SM129 & 2,45 & 2,578 \\
\hline SM144 & 2,25 & 2,183 \\
\hline SM146 & 2,05 & 1,825 \\
\hline SM168 & 1,78 & 1,368 \\
\hline SM179 & 1,49 & 0,304 \\
\hline SM191 & 1,94 & 1,632 \\
\hline SM212 & 0,63 & 0,218 \\
\hline SM238 & 0,37 & 0,022 \\
\hline Total Susut (KW) & & 21,1790 \\
\hline Jam (Perhitungan) & $\begin{array}{l}\text { 31 Jan -5 Feb } \\
2020\end{array}$ & 144 \\
\hline Total Susut (kWh) & & 3049,776 \\
\hline
\end{tabular}

Berdasarkan tabel hasil simulasi pada Etap 12.6 dapat diketahui bahwa susut daya distribusi tegangan menengah Penyulang Nijang jika digunakan Simulasi sebesar 3049,776 kWh.

\section{Nilai Susut Daya}

Berikut merupakan hasil perhitungan susut trafo pada Penyulan Nijang.

Tabel Hasil Perhitungan Susut Trafo di Penyulang Nijang

\begin{tabular}{|c|c|c|c|c|c|}
\hline Gardu & $\begin{array}{l}\text { Alamat } \\
\text { Gardu }\end{array}$ & $\begin{array}{c}\text { Kapasitas } \\
\text { (KVA) }\end{array}$ & $\begin{array}{c}\text { Rugi } \\
\text { Besi } \\
\text { (KW) }\end{array}$ & $\begin{array}{c}\text { Rugi } \\
\text { Tembaga } \\
\text { (KW) }\end{array}$ & $\begin{array}{l}\text { Susut } \\
\text { Trafo } \\
\text { (kWh) }\end{array}$ \\
\hline SM028 & SMA 3 & 160 & 0,4 & 2,000 & 86,410 \\
\hline SM043 & KP. Padak & 160 & 0,4 & 2,000 & 86,408 \\
\hline SM073 & SNAKMA & 200 & 0,48 & 2,500 & 103,687 \\
\hline SM079 & $\begin{array}{l}\text { BTN Griya } \\
\text { Idola }\end{array}$ & 160 & 0,4 & 2,000 & 86,413 \\
\hline SM093 & $\begin{array}{l}\text { Kampung } \\
\text { Padak }\end{array}$ & 50 & 0,15 & 0,800 & 32,402 \\
\hline SM098 & Cendrawasih & 160 & 0,4 & 2,000 & 86,405 \\
\hline SM129 & $\begin{array}{l}\text { Depan TK. } \\
\text { Kauman }\end{array}$ & 160 & 0,4 & 2,000 & 86,418 \\
\hline SM144 & $\begin{array}{l}\text { Gunung } \\
\text { Setia }\end{array}$ & 160 & 0,4 & 2,000 & 86,416 \\
\hline SM146 & $\begin{array}{l}\text { Transito } \\
\text { (Sisipan 73) }\end{array}$ & 160 & 0,4 & 2,000 & 86,414 \\
\hline SM168 & $\begin{array}{l}\text { BTN Olat } \\
\text { Rarang }\end{array}$ & 160 & 0,4 & 2,000 & 86,410 \\
\hline
\end{tabular}




\begin{tabular}{|c|c|c|c|c|c|}
\hline SM179 & $\begin{array}{l}\text { Mesjid KP } \\
\text { Padak }\end{array}$ & 50 & 0,15 & 0,800 & 32,402 \\
\hline SM191 & Gang Asdek & 100 & 0,3 & 1,600 & 64,811 \\
\hline SM235 & $\begin{array}{l}\text { BTN } \\
\text { Samota }\end{array}$ & 200 & 0,48 & 0,000 & 0,000 \\
\hline SM213 & $\begin{array}{l}\text { Hotel } \\
\text { Absara }\end{array}$ & 200 & 0,48 & 0,000 & 0,000 \\
\hline SM238 & $\begin{array}{l}\text { Samota } \\
\text { Ujung }\end{array}$ & 100 & 0,3 & 1,600 & 64,800 \\
\hline SM212 & $\begin{array}{l}\text { Koncrete } \\
\text { Koboi }\end{array}$ & 200 & 0,48 & 2,500 & 103,680 \\
\hline MH043 & $\begin{array}{l}\text { Hotel } \\
\text { Lamono }\end{array}$ & 100 & 0,3 & 1,600 & 64,802 \\
\hline MH056 & $\begin{array}{l}\text { PT BSA } \\
\text { Labu Sawo }\end{array}$ & 200 & 0,48 & 2,500 & 103,680 \\
\hline MH042 & $\begin{array}{l}\text { Desa } \\
\text { Labuhan } \\
\text { Sawo }\end{array}$ & 50 & 0,15 & 0,800 & 32,400 \\
\hline MH041 & Desa Omo & 50 & 0,15 & 0,800 & 32,400 \\
\hline MH057 & $\begin{array}{l}\text { Tambak } \\
\text { Labu Sawo }\end{array}$ & 250 & 0,6 & 3,000 & 129,604 \\
\hline MH059 & Alor Jaya & 200 & 0,48 & 2,500 & 103,681 \\
\hline \multicolumn{5}{|c|}{ Total Susut Trafo } & 1559,64 \\
\hline
\end{tabular}

Dari tabel diatas dapat diketahui bahwa susut trafo di sepanjang penyulang nijang $1559,64 \mathrm{kWh}$

\section{Nilai Susut Jaringan Distribusi}

Perhitungan Susut Jaringan Distribusi menggunakan persamaan 2.7 dan persamaan 2.8. Perhitungan Susut Jaringan Distribusi dilakukan dengan membagi 3 bagian sebagai berikut :

1. Penampang AAAC $70 \mathrm{~mm} 2$

Dimulai dengan menghitung resistansi menggunakan persamaan 2.2 dan persamaan 2.3 yang diketahui berdasarkan tabel AAAC sesuai SPLN 41-8:1981 diketahui bahwa nilai t1 $20^{\circ} \mathrm{C}$, t2 $60^{\circ} \mathrm{C}$ dan Rt1 sebesar 0,438, maka :

$\mathrm{R}_{\mathrm{t} 2}=\frac{\mathrm{T}+\mathrm{t} 2}{\mathrm{~T}+\mathrm{t} 1} \times \mathrm{R}_{\mathrm{t} 1}$

$\mathrm{R}_{\mathrm{t} 2}=\frac{228,1+60}{228,1+20} \times 0,438$

$\mathrm{R}_{\mathrm{t} 2}=0,5086 \mathrm{Ohm} / \mathrm{km}$

Setelah diketahui $R_{\mathrm{t} 2}$ selanjutnya dilanjutkan mencari Rac

$\mathrm{R}_{\mathrm{ac}}=\mathrm{K} \times \mathrm{R}_{\mathrm{t} 2}$

$\mathrm{R}_{\mathrm{ac}}=1,02 \times 0,5086 \mathrm{Ohm} / \mathrm{km}$

$\mathrm{R}_{\mathrm{ac}}=0,51870 \mathrm{hm} / \mathrm{km}$

Selanjutnya mencari Rugi Beban Puncak pada penampang dengan panjang penampang, diketahui FKjtm $=1$ :

$\mathrm{P}_{\mathrm{rp}}=3 \times \mathrm{I}_{\text {bbn puncak }}{ }^{2} \times \mathrm{R}_{\mathrm{ac}} \times l \times \mathrm{FK}_{\text {jtm }}$

$P_{\mathrm{rp}}=3 \times 34^{2} \times 0,5187 \times 6,76609 \times 1$

$\mathrm{P}_{\mathrm{rp}}=12,173 \mathrm{KW}$

Dari Rugi daya beban puncak dapat digunakan mencari Susut daya dengan terlebih dahulu mencari Loss Load Faktor (LLF), diketahui Load Faktor (LF) pada penyulang nijang sebesar 0,7783 , sehingga dapat dihitung :

$\mathrm{LLF}=0,7 \times \mathrm{LF}^{2}+0,3 \times \mathrm{LF}$

$\operatorname{LLF}=0,7 \times 0,7783^{2}+0,3 \times 0,7783$

$\mathrm{LLF}=0,6575$

Kemudian dilanjutkan dengan mencari susut daya pada penampang $70 \mathrm{~mm} 2$ Penyulang
Nijang :

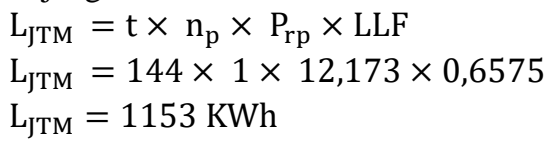

2. Penampang A3C/A3CS $150 \mathrm{~mm} 2$

Sesuai SPLN 41-8:1981 diketahui bahwa nilai t1 $20^{\circ} \mathrm{C}$, t2 $60^{\circ} \mathrm{C}$ dan Rt1 sebesar 0,210, maka :

$\mathrm{R}_{\mathrm{t} 2}=\frac{\mathrm{T}+\mathrm{t} 2}{\mathrm{~T}+\mathrm{t} 1} \times \mathrm{R}_{\mathrm{t} 1}$

$\mathrm{R}_{\mathrm{t} 2}=\frac{228,1+60}{228,1+20} \times 0,210$

$\mathrm{R}_{\mathrm{t} 2}=0,2438 \mathrm{Ohm} / \mathrm{km}$

Setelah diketahui $R_{t 2}$ selanjutnya dilanjutkan mencari Rac

$\mathrm{R}_{\mathrm{ac}}=\mathrm{K} \times \mathrm{R}_{\mathrm{t} 2}$

$\mathrm{R}_{\mathrm{ac}}=1,02 \times 0,2438 \mathrm{Ohm} / \mathrm{km}$

$\mathrm{R}_{\mathrm{ac}}=0,24870 \mathrm{hm} / \mathrm{km}$

Selanjutnya mencari Rugi Beban Puncak pada penampang dengan panjang penampang, diketahui FKjtm $=0,91$ :

$\mathrm{P}_{\mathrm{rp}}=3 \times \mathrm{I}_{\text {bbn puncak }}{ }^{2} \times \mathrm{R}_{\mathrm{ac}} \times l \times \mathrm{FK}_{\mathrm{jtm}}$

$P_{\mathrm{rp}}=3 \times 34^{2} \times 0,2487 \times 19,765 \times 0,91$

$\mathrm{P}_{\mathrm{rp}}=15,515 \mathrm{KW}$

Dari Rugi daya beban puncak dapat digunakan mencari Susut daya dengan terlebih dahulu mencari Loss Load Faktor (LLF), diketahui Load Faktor (LF) pada penyulang nijang sebesar 0,7783 , sehingga dapat dihitung :

$\mathrm{LLF}=0,7 \times \mathrm{LF}^{2}+0,3 \times \mathrm{LF}$

$\operatorname{LLF}=0,7 \times 0,7783^{2}+0,3 \times 0,7783$

$\mathrm{LLF}=0,6575$

Kemudian dilanjutkan dengan mencari susut daya pada penampang $150 \mathrm{~mm} 2$ Penyulang Nijang :

$$
\begin{aligned}
& \mathrm{L}_{\text {JTM }}=\mathrm{t} \times \mathrm{n}_{\mathrm{p}} \times \mathrm{P}_{\mathrm{rp}} \times \mathrm{LLF} \\
& \mathrm{L}_{\mathrm{JTM}}=144 \times 1 \times 15,515 \times 0,6575 \\
& \mathrm{~L}_{\mathrm{JTM}}=1469 \mathrm{KWh}
\end{aligned}
$$

3. Penampang NA2XSEYBY $150 \mathrm{~mm} 2$

Sesuai SPLN 43-5/IEC 60502-2 diketahui bahwa nilai t1 $20^{\circ} \mathrm{C}$, t2 $60^{\circ} \mathrm{C}$ dan Rt1 sebesar 0,206 , maka :

$$
\begin{aligned}
& \mathrm{R}_{\mathrm{t} 2}=\frac{\mathrm{T}+\mathrm{t} 2}{\mathrm{~T}+\mathrm{t} 1} \times \mathrm{R}_{\mathrm{t} 1} \\
& \mathrm{R}_{\mathrm{t} 2}=\frac{228,1+60}{228,1+20} \times 0,206 \\
& \mathrm{R}_{\mathrm{t} 2}=0,2392 \mathrm{Ohm} / \mathrm{km}
\end{aligned}
$$

Setelah diketahui $\mathrm{R}_{\mathrm{t} 2}$ selanjutnya dilanjutkan mencari Rac

$\mathrm{R}_{\mathrm{ac}}=\mathrm{K} \times \mathrm{R}_{\mathrm{t} 2}$

$$
\mathrm{R}_{\mathrm{ac}}=1,02 \times 0,2392 \mathrm{Ohm} / \mathrm{km}
$$

$\mathrm{R}_{\mathrm{ac}}=0,24390 \mathrm{hm} / \mathrm{km}$

Selanjutnya mencari Rugi Beban Puncak pada penampang dengan panjang penampang, diketahui FKjtm $=0,91$ :

$$
\begin{aligned}
& \mathrm{P}_{\mathrm{rp}}=3 \times \mathrm{I}_{\text {bbn puncak }}{ }^{2} \times \mathrm{R}_{\mathrm{ac}} \times l \times \mathrm{FK}_{\mathrm{jtm}} \\
& \mathrm{P}_{\mathrm{rp}}=3 \times 34^{2} \times 0,2439 \times 0,214 \times 1 \\
& \mathrm{P}_{\mathrm{rp}}=0,1810 \mathrm{KW}
\end{aligned}
$$


dari Rugi daya beban puncak dapat digunakan mencari Susut daya dengan terlebih dahulu mencari Loss Load Faktor (LLF), diketahui Load Faktor (LF) pada penyulang nijang sebesar 0,7783 , sehingga dapat dihitung :

$\mathrm{LLF}=0,7 \times \mathrm{LF}^{2}+0,3 \times \mathrm{LF}$

$L L F=0,7 \times 0,7783^{2}+0,3 \times 0,7783$

$\mathrm{LLF}=0,6575$

Kemudian dilanjutkan dengan mencari susut daya pada penampang NA2XSEYBY $150 \mathrm{~mm} 2$ Penyulang Nijang :

$\mathrm{L}_{\mathrm{JTM}}=\mathrm{t} \times \mathrm{n}_{\mathrm{p}} \times \mathrm{P}_{\mathrm{rp}} \times \mathrm{LLF}$

$\mathrm{L}_{\mathrm{JTM}}=144 \times 1 \times 0,1810 \times 0,6575$

$\mathrm{L}_{\mathrm{JTM}}=17,15 \mathrm{KWh}$

Sehingga susut pada penampang jaringan 2.639 KWh, sedangkan untuk menghitung Susut total Jaringan Penyulang Nijang perhitungan didapatkan

$\mathrm{L}_{\mathrm{TM}}=\mathrm{L}_{\mathrm{GD}}+\mathrm{L}_{\mathrm{JTM}}$

$\mathrm{L}_{\mathrm{TM}}=1559,65 \mathrm{KWh}+2639 \mathrm{KWh}$

$\mathrm{L}_{\mathrm{TM}}=4199 \mathrm{KWh}$

\section{Perhitungan Susut Daya dengan Rekonsiliasi Energi}

Rekonsiliasi energi dilakukan dengan membadingkan kWh yang ada di pangkal jaringan penyulang nijang yaitu di kubikel dengan $\mathrm{kWh}$ yang ada di gardu sepanjang jaringan penyulang nijang mulai dari tanggal 31 Januari 2020 sampai tanggal 5 Februari 2020. kWh di dapat dengan cara mendownload titik transaksi (kWh Meter), berikut ini adalah hasilnya.

Tabel hasil Rekonsiliasi Energi di Penyulang Nijang

\begin{tabular}{|l|l|r|}
\hline \multicolumn{1}{|c|}{ Gardu } & \multicolumn{1}{|c|}{ Alamat } & \multicolumn{1}{c|}{ kWh Produksi } \\
\hline SM028 & SMA 3 & 10230,4 \\
\hline SM043 & KP. Padak & 8807,6 \\
\hline SM073 & SNAKMA & 13165,6 \\
\hline SM079 & BTN Griya Idola & 10779,04 \\
\hline SM093 & Kampung Padak & 2221,6 \\
\hline SM098 & Cendrawasih & 7378,2 \\
\hline & $\begin{array}{l}\text { Depan TK. } \\
\text { Kauman }\end{array}$ \\
\hline LM129 & Labuhan & 12590,8 \\
\hline SM144 & Gunung Setia & 12982,3 \\
\hline SM146 & $\begin{array}{l}\text { Transito (Sisipan } \\
\text { 73) }\end{array}$ & 12320,2 \\
\hline SM168 & $\begin{array}{l}\text { BTN Olat } \\
\text { Rarang }\end{array}$ & 6134,96 \\
\hline SM179 & $\begin{array}{l}\text { Mesjid KP } \\
\text { Padak }\end{array}$ & 2557,36 \\
\hline SM191 & Gang Asdek & 9411,36 \\
\hline SM235 & BTN Samota & 0 \\
\hline SM213 & $\begin{array}{l}\text { Samota-Hotel } \\
\text { Absara }\end{array}$ & \\
\hline SM238 & Samota Ujung & \\
\hline & & \\
\hline
\end{tabular}

\begin{tabular}{|l|l|r|} 
& KM212 & 1004,1 \\
\hline MH043 & Hotel Lamono & 1044,4136 \\
\hline MH056 & $\begin{array}{l}\text { PT BSA Labu } \\
\text { Sawo }\end{array}$ & 0 \\
\hline MH042 & $\begin{array}{l}\text { Desa Labuhan } \\
\text { Sawo }\end{array}$ & 673,5019355 \\
\hline MH041 & Desa Omo & 749,632 \\
\hline MH057 & $\begin{array}{l}\text { Tambak Labu } \\
\text { Sawo Ujung }\end{array}$ & 5574,54 \\
\hline MH059 & $\begin{array}{l}\text { Penyaring Alor } \\
\text { Jaya }\end{array}$ & 168,3 \\
\hline \multicolumn{2}{|r|}{ Total kWh Gardu } & $\mathbf{1 1 7 8 3 8 , 9 0 7 5}$ \\
\hline \multicolumn{2}{|c|}{ Produksi Penyulang Nijang } & $\mathbf{1 2 8 4 9 6 , 2 9 1 8}$ \\
\hline \multicolumn{2}{|c}{ Susut } & $\mathbf{1 0 6 5 7 , 3 8 4 3}$ \\
\hline
\end{tabular}

Dari data tersebut dapat disimpulkan bahwa jaringan penyulang nijang berdasarkan proses rekonsiliasi energi pada tanggal 31 januari sampai 5 Februari 2020 didapatkan susut daya

\section{PENUTUP}

\section{Kesimpulan}

Kesimpulan yang didapatkan dari hasil analisis susut daya hasil program rekonsiliasi energi, Simulasi ETAP 12.6 dan Perhitungan listrik terapan pada penelitian ini adalah:

1. Analisis susut rekonsiliasi energi mempunyai hasil Susut Daya Paling Besar dengan besar susut $10.657,38 \mathrm{kWh}$ jika dibandingkan dengan Simulasi ETAP 12.6 dengan hasil 3049,77 kWh dan Perhitungan Manual sebesar 4198,64 $\mathrm{kWh}$. Beberapa hal yang mempengaruhi diantaranya :

a. Faktor sambungan yang menambah nilai resistansi pada penampang atau gardu distribusi yang tidak diperhitungkan pada Simulasi Etap 12.6 dan perhitungan manual.

b. Kondisi trafo yang ideal sehingga dianggap tidak ada rugi-rugi Trafo yang di akibatkan unbalance trafo.

c. Error pengukuran pada rekonsiliasi energi bisa juga mempengaruhi besarnya nilai rekonsiliasi energi.

2. Analisis susut daya menggunakan perhitungan dan simulasi ETAP 12.6 menghasilkan susut relative sama, karena semua parameternya dianggap ideal sedangkan nilai Rekonsiliasi Energi akan lebih besar karena sudah termasuk susut jaringan non teknis

\section{Saran}

Berdasarkan hasil penelitian dan kesimpulan yang sudah ditarik, maka adapun saran yang bisa diberikan antara lain:

1. Pada proses rekonsiliasi energi hanya digunakan data mulai tanggal 31 Januari sampai 5 Februari 2020. Sedangkan di PLN, kinerja susut daya dihitung secara bulanan, sehingga diharapkan kepada para peneliti selanjutnya untuk melakukan penelitian dengan data bulanan. 
2. Peneliti selanjutnya bisa melakukan penelitian secara lebih lengkap sampai ke pelanggan (konsumen).

3. Kelengkapan pada data dan instrumen mempengaruhi hasil simulasi dari kinerja sistem sehingga dapat mengurangi penggunaan ketetapan (default) yang terdapat pada simulasi program.

\section{REFERENSI}

Amiruddin. (2010). Statistik Pendidikan. Yogyakarta: Teras.

Binilang, R. B. (2017). Studi Analisa Rugi Daya Pada Saluran Distribusi Primer $20 \mathrm{kV}$ di Kota Tahuna. E-Journal Teknik Elektro dan Komputer vol. 6 no.2, 69.

Hutauruk, T. (1985). “Transmisi Daya Listrik". Jakarta: Erlangga.

Marniati, Y., \& Hanifatulah, Q. A. (2018). Evaluasi Susut Daya Penyulang Cendana $20 \mathrm{kV}$ pada Gardu Induk Bungaran dengan ETAP 12.6. Jurnal Teknik Elektro UTP, Vol. 7.

Pramono, T. J., Erlina, Soewono, S., \& Fatimah. (2018). Analisis Drop Tegangan Pada Jaringan Tegangan Menengah Dengan Menggunakan Simulasi Program ETAP. Jurnal \& Kelistrikan Vol. 10 No. 1, 26.

PT PLN (Persero). (1981). SPLN 41-8:1981. Jakarta: PT PLN (Persero).

PT PLN (Persero). (1991). SPLN 87 :1991. Jakarta: PT PLN (Persero).

PT PLN (Persero). (2010). Buku 1 Kriteria Disain Enjinering Kontruksi Jaringan Distribusi
Tenaga Listrik. Jakarta Selatan: PT PLN (Persero).

PT PLN (Persero). (2010). Buku 5 Standar Kontruksi Jaringan Tegangan Menengah Tenaga Listrik. Jakarta Selatan: PT PLN (Persero).

PT PLN (Persero). (2018). Pedoman Teknis Penerapan Formula Susut Jaringan Tenaga Listrik di Lingkungan PT PLN (Persero).

Purnomo, H. (2016). Analisis Sistem Daya I (Bagian Saluran Transmisi Daya Elektrik). Malang: Fakultas Teknik Universitas Brawijaya.

Putranti, R. D. (2014). Perhitungan Kerugian Energi Pada Penyulang Tambak Lorok - 03 Sebagai salah satu project Program Revass (Revenue Assurance) dalam program Rekonsiliasi Energi PT. PLN (Persero) Area Semarang. Gema Teknologi Vol. 18 No. $1,16$.

Sugiyono. (2011). Metode Penelitian Kuantitatif, kualitatif dan $R \&$ \& . Bandung: Alfabeta.

Tanzeh, S. (2006). “Dasar-Dasar Penelitian”. Surabaya: Lembaga Kajian Agama Dan Filsafat (eLKAF).

Tenda, N. (2016). Penyusutan Daya Listrik Pada Penyulang Jaringan Transmisi Isimu Marisa. E-Journal Teknik Elektro dan Komputer vol. 5 no. 1, 75 . 